\title{
Self-Presentation Komunitas Indonesian Subculture Melawan Stigma Kriminalitas
}

\author{
Ronald Yehezkiel Jasita ${ }^{1}$, Gregorius Genep Sukendro ${ }^{2 *}$ \\ ${ }^{1}$ Fakultas Ilmu Komunikasi, Universitas Tarumanagara \\ Email: ronaldyehezkielj@gmail.com \\ ${ }^{2}$ Fakultas Ilmu Komunikasi, Universitas Tarumanagara* \\ Email: geneps@fikomuntar.ac.id
}

Masuk tanggal: 15-12-2021, revisi tanggal: 06-01-2022, diterima untuk diterbitkan tanggal: 16-01-2022

\begin{abstract}
In Indonesia, there are still many assumptions that people with tattoos are synonymous with criminal behavior. Seeing the stigma of criminality against tattoos in society, this is the beginning of the formation of the Indonesian Subculture community. Indonesian Subculture is one of the tattoo communities in Jakarta that has been formed since July 9, 2004. This community is slowly changing its assessment of people with tattoos. This is related to the self-presentation displayed by Indonesian Subculture in the community in fighting the stigma of tattooing as one of the characteristics of a criminal in society. Therefore, the authors are interested in conducting research with a qualitative approach and case study research methods. The purpose of this study is to determine the self-presentations presented by Indonesian Subculture in an effort to fight the stigma of crime in society. The data analyzed were the result of interviews, direct observation, and documentation. The results showed that the self-presentation shown by Indonesian Subculture in fighting the stigma of crime in society was to form a positive community concept through the slogan and vision and mission, namely always having safe and healthy tattoos / piercing, holding various positive activities. These activities include a coaching clinic, social service, tattoo and piercing competitions, as well as tattoo / piercing educational activities.
\end{abstract}

Keywords: construction sosial reality, criminal stigma, self-presentation, tattoo

\begin{abstract}
Abstrak
Di Indonesia, masih banyak anggapan orang bertato identik dengan perilaku tindak kriminal. Melihat adanya stigma kriminalitas terhadap tattoo di masyarakat, menjadi awal mula terbentuknya komunitas Indonesian Subculture. Indonesian Subculture merupakan salah satu komunitas tattoo di Jakarta yang telah dibentuk sejak 9 Juli 2004. Komunitas ini perlahan mengubah penilaian terhadap orang bertato. Hal ini berkaitan dengan self-presentation yang ditampilkan Indonesian Subculture di masyarakat dalam melawan stigma tattoo sebagai salah satu ciri seorang pelaku tindak kriminalitas di masyarakat. Oleh karena itu, penulis tertarik untuk melakukan penelitian dengan pendekatan kualitatif dan metode penelitian studi kasus. Adapun tujuan dari penelitian ini adalah untuk mengetahui self-presentation yang ditampilkan Indonesian Subculture dalam upaya melawan stigma kriminalitas di masyarakat. Data yang dianalisis merupakan hasil wawancara, pengamatan langsung, serta dokumentasi. Hasil penelitian menunjukkan bahwa self-presentation yang ditunjukan Indonesian Subculture dalam melawan stigma kriminalitas di masyarakat adalah membentuk konsep komunitas yang positif melalui slogan dan visi misi yakni selalu bertato/piercing yang aman dan sehat, menyelenggarakan berbagai kegiatan-kegiatan positif. Kegiatan tersebut antara lain coaching clinic, bakti sosial, lomba tattoo dan piercing, serta kegiatan edukasi bertato/piercing.
\end{abstract}

Kata kunci: konstruksi realitas sosial, self-presentation, stigma kriminalitas, tattoo 


\section{Pendahuluan}

Berkomunikasi yang baik adalah dapat menyampaikan pesan kepada lawan bicaranya tidak hanya melalui pesan atau kata-kata saja. Melainkan harus seimbang dalam penyampaian pesan dan gerak-gerik orang tersebut untuk meyakinkan lawan bicaranya. Dalam perkembangan jaman yang semakin modern, simbol dan kode komunikasi juga bisa diartikan melalui tato. Karena terdapat makna tersendiri yang dapat berubah sebagai pesan terhadap masyarakat sekitar dan banyak masyarakat yang beranggapan tatto sebagian dari fashion. Tetapi masih banyak masyarakat yang mempunyai stigma buruk dan menganggap orang yang mempunyai tato itu buruk, khususnya di Indonesia.

Masyarakat Indonesia masih banyak yang menilai bahwa orang bertato sering diidentikkan dengan perilaku tindak kriminal. Masyarakat juga sering berasumsi mentato bagian tubuh merupakan salah satu bentuk kriminalitas. Asumsi masyarakat mengenai orang bertato memang tidak sepenuhnya salah. Beberapa penelitian mengungkapkan bahwa hampir semua preman-preman, pencuri, dan gangster memiliki tato di tubuhnya. Pada akhirnya, asumsi tersebut menimbulkan sebuah stigma negatif bahwa orang bertato identik dengan tindakan kriminal.

Menurut Siegel (2000), pada era Presiden Soeharto, terdapat kasus nyata yang bernama Petrus 1980-an atau penembakan misterius dimana yang menjadi sasaran adalah orang-orang jahat atau berandalan yang dianggap mengganggu ketentraman masyarakat. Untuk mengenali orang jahat atau berandalan, si penembak menculik orang-orang dengan gaya berandalan dan bertato. Dalam sistem yang dilakukan Soeharto terhadap orang bertato pada waktu itu berhasil memberikan ancaman yang tegas dan banyak orang yang berdatangan kerumah sakit untuk dihilangkan tatonya meskipun orang tersebut bukanlah orang jahat atau berandalan. Akhirnya, anggapan kriminal dan penjahat sulit dirubah ketika melihat orang bertato. Hal ini didukung oleh penelitian yang dilakukan Fattahurrosyid (2016). Dalam hasil penelitiannya, Fattahurrosyid (2016) menyatakan bahwa konstruksi realitas sosial yang terjadi pada komunitas tato di Malang masih terdapatnya diskriminasi dari masyarakat akibat stigma yang dibentuk sejak dulu.

Seiring berjalannya waktu, penggunaan tato tidak lagi mempedulikan adanya stigma negatif di masyarakat. Banyaknya informasi yang diterima pelan-pelan mengubah pandangan sebagian masyarakat bahwa tato adalah bentuk dari seni. Menurut Olong (2006), berbagai jenis kalangan mulai banyak menggemari tato, bahkan kaum wanita sekalipun. Semakin hari, semakin banyak komunitas tato yang terbentuk dan tidak jarang komunitas yang mendapatkan penolakan dari masyarakat sekitar. Meskipun begitu, beberapa komunitas tato memberikan perlawanan terhadap stigma buruk terhadap orang-orang bertato dengan beberapa tindakan positif. Komunitas tersebut menghasilkan sebuah pemikiran positif dari masyarakat, sehingga anggota komunitas merasa diterima dilingkungan sekitarnya. Salah satu komunitas tato tersebut yaitu Indonesia Subculture (sumber: Facebook Indonesian Subculture).

Indonesian Subculture merupakan salah satu komunitas tattoo di Jakarta yang telah dibentuk sejak 9 Juli 2004 (sumber: Facebook Indonesian Subculture). Eksistensinya di dunia seni tato sudah diakui dengan apresiasi dan partisipasi masyarakat (sumber: Facebook Indonesian Subculture). Hal ini berkaitan dengan self-presentation yang ditampilkan Indonesian Subculture di masyarakat. 
Menurut Goffman (dalam Worchel, Cooper, Goethals, dan Olson, 2000), selfpresentation adalah upaya yang dilakukan individu atau kelompok dalam rangka membentuk apa yang orang lain pikirkan tentang individu/kelompok tersebut dan apa yang individu/kelompok tersebut pikirkan tentang diri mereka sendiri. Selfpresentation diibaratkan sebagai tindakan yang dilakukan individu/kelompok untuk menampilkan dirinya di depan publik agar tercapai citra diri yang diharapkan. Morley (2002) menggarisbawahi bahwa pengelolaan reputasi melalui selfpresentation yang positif hingga tercapainya citra diri positif bagi individu/kelompok, mampu mempromosikan dan melindungi eksistensi individu/kelompok tersebut. Selanjutnya, Jones dan Pittman (1982) menyatakan lima strategi dalam selfpresentation, antara lain self-promotion, ingratiation, intimidation, exemplification, dan supplication.

Indonesian Subculture sebagai salah satu komunitas tattoo di Inonesia perlahan bisa mengubah penilaian terhadap orang bertato menjadi lebih baik. Saat ini Indonesian Subculture juga sudah bekerja sama dengan berbagai komunitas tato lain yang ada di Indonesia dengan membuat beberapa pagelaran positif. Berdasarkan latar belakang yang telah diuraikan sebelumnya oleh peneliti, peneliti melakukan penelitian dengan judul "Self-presentation Indonesian Subculture dalam Melawan Stigma Kriminalitas". Penelitian lebih memfokuskan kepada stigma negatif masyarakat terhadap tato dan strategi self-presentation yang digunakan dalam upaya melawang stigma kriminalitas.

\section{Metode Penelitian}

Pada penelitian ini, peneliti menggunakan pendekatan kualitatif. Menurut Auerbach dan Silverstein (dalam Sugiyono, 2020), pendekatan kualitatif adalah penelitian yang melakukan analisis dan interpretasi teks dan hasil interview dengan tujuan untuk menemukan makna dari suatu fenomena. Penelitian kualitatif berkenaan dengan data bukan angka, di mana peneliti mengumpulkan dan menganalisis data yang bersifat naratif.

Penelitian ini menggunakan metode penelitian deskriptif-studi kasus. Menurut Rahardjo (2017), studi kasus merupakan serangkaian kegiatan ilmiah yang dilakukan secara intensif, terinci, dan mendalam tentang suatu program, peristiwa, dan aktivitas, baik pada perorangan, kelompok, lembaga, atau organisasi untuk memperoleh pengetahuan mendalam tentang peristiwa tersebut. Peneliti menggunakan metode studi kasus dengan maksud ingin mendeskripsikan hasil penelitian dan berusaha menemukan gambaran menyeluruh mengenai selfpresentation yang ditunjukan komunitas Indonesian Subculture dalam melawan stigma kriminalitas.

Peneliti melakukan wawancara terhadap informan kunci yakni Ketua Komunitas Indonesian Subculture Efraim Kurdian Baginda Pangaribuan atau yang akrab dipanggil Ucha. Untuk mengumpulkan data yang diperlukan, penulis menggunakan metode observasi, wawancara, dan dokumentasi.

\section{Hasil Temuan dan Diskusi}

Indonesian Subculture adalah sebuah organisasi yang bergerak di bidang seni budaya rajah/tato dan tindik tubuh. Indonesian Subculture didirikan pada Juli 2004. Indonesian Subculture didirikan untuk menghadapi berbagai macam masalah seiring 
dengan meningkatnya kekhawatiran masyarakat tentang kesehatan dan keamanan dalam industri tato/tindik Indonesia.

\section{Konstruksi Realitas Sosial mengenai Tato}

Dalam perkembangan jaman yang semakin modern, simbol dan kode komunikasi juga bisa diartikan melalui tato. Akan tetapi, masyarakat Indonesia masih banyak yang menilai bahwa tato merupakan hal yang tabu karena bisa menimbulkan efek yang kurang baik bagi tubuh. Hal ini dijelaskan oleh informan: "Kalau diterima sih enggak semudah itu. Ada histori dari kita ini pelaku-pelaku sebagai pembuat. Kita ditato ditindik, masyarakat banyak yang khawatir pada saat itu karena penyakit yang diakibatkan dari tato".

Masyarakat Indonesia masih banyak yang menilai bahwa orang bertato sering diidentikkan dengan perilaku tindak kriminal. Masyarakat juga sering memberikan asumsinya bahwa me-natto bagian tubuh merupakan salah satu bentuk kriminilitas. Asumsi masyarakat mengenai orang bertato memang tidak sepenuhnya salah. Beberapa penelitian mengungkapkan bahwa hampir semua preman, pencuri, dan gangster memiliki tatto di tubuhnya. Pada akhirnya, asumsi tersebut menimbulkan sebuah stigma negatif bahwa orang bertato identik dengan tindakan kriminal. Hal ini dialami secara pribadi oleh informan.

\section{Self-Presentation Indonesian Subculture}

Indonesian Subculture sering mengadakan kegiatan untuk berbagi informasi dan edukasi tentang standar prosedur bagi para pekerja seni tato dan tindik mengenai hal pengendalian, pencegahan, hingga terjadinya peningkatan penyebaran penyakit. Kegiatan edukasi ini dilakukan diseluruh media sosial Indonesian Subculture.Kegiatan edukasi tak hanya dilakukan melalui media sosial saja, tetapi juga mereka lakukan secara offline, seperti di sekolah dan universitas. Selama melakukan kegiatan edukasi di sekolah dan universitas, Indonesian Subculture menemukan banyak sekali pengguna tindik atau tato, baik tato permanen maupun sementara. Hal ini dijelaskan oleh informan sebagai berikut, "Gue pernah di Labschool Rawamangun. kita pengen mengedukasi. Pas gue tanya siapa yang pernah tindik dan tattoo permanent? Mereka ga ada yang jawab. Pernah tato temporary? dan mereka hampir $80 \%$ angkat tangan semua."

Adapun pesan yang disampaikan dalam kegiatan edukasi tersebut adalah cara penggunaan tato dan tindik yang sehat dan aman. Indonesian Subculture memberikan coaching clinic dan operasional prosedur dalam melakukan tindik atau membuat tato. Dari kegiatan ini, Indonesian Subculture tidak hanya merasa diterima, melainkan mendapatkan kesempatan untuk memberikan edukasi kepada para pelaku tato/tindik. "Ya akhirnya kita bilang, kalau mau melakukan hal something apa aja, ini loh cara yang benernya, gitu... Kita bikin coaching clinic, kasih tau dari tukang tatonya sampai yang pengen ditatonya. Dan pada saat akhirnya, kita bukannya diterima, tapi kita sudah bisa mengedukasikan gimana sih melakukan tato yang betul-betul sesuai operasional prosedurnya. Jadi, gue tetep pada slogannya anak-anak ISC tuh supaya tato ini dijalur kesenian yang aman dan sehat."

Selain mengedukasi para pelaku tato dan tindik, Indonesian Subculture juga banyak melakukan kegiatan sosial, misalnya kegiatan bakti sosial. Melalui kegiatankegiatan yang positif ini, Indonesian Subculture berusaha mempresentasikan komunitas ini sebagai komuntas yang positif sehingga Indonesian Subculture memiliki citra yang positif juga di masyarakat. Hal ini dijelaskan oleh informan 
sebagai berikut "Ya yang tadi kita uda bilang ya. Sharing mengedukasi, baksos, semua boleh diliat di instagram. Kita dari awal ngebantu melalui kerja sosial ini bener-bener pure dapet citra kalau oh anak tato tuh gak sejahat yang mereka pikir. Ya itu bukan pencintraan sih sebenernya, ya karena tulus aja. Semua berjalaan sebegitunya."

\section{Kegiatan dan Upaya Indonesian Subculture}

Berdasarkan hasil telaah dan dokumentasi, kegiatan sosial yang pernah diselenggarakan oleh Indonesian Subculture, antara lain menggalang donasi untuk korban bencana alam di Indonesia dan sesama anggota komunitas yang tertimpa musibah, mengunjungi panti jompo, dll. Berikut adalah beberapa contoh kegiatan sosial yang telah diselenggarakan oleh Indonesian Subculture. Selain mengadakan kegiatan edukasi dan sosial, Indonesian Subculture juga mengadakan kegiatankegiatan lainnya, seperti perlombaan tato, konser musik, pameran tato, dll. Berdasarkan hasil telaah dokumentasi, berikut adalah beberapa acara seni yang pernah diselenggarakan oleh Indonesian Subculture. Indonesian Subculture juga mempresentasikan komunitasnya sebagai suatu komunitas aman dan sehat yang berusaha untuk menekan stigma negatif dari masyarakat mengenai penyakit yang ditimbulkan dari tato atau tindik. Untuk pengguna tato, Indonesian Subculture menyarankan untuk mencari tempat tato yang benar-benar memerhatikan soal keamanan dan telah melalui pertimbangan yang matang. Bagi artis tato, terdapat hal yang patut diperhatikan, yakni masalah keamanan dan higienis. Alat yang hanya digunakan sekali pakai harus dibuang dalam tempat khusus, sedangkan yang akan dipergunakan kembali harus disterilisasi untuk menjaga higienitasnya (Marzuqi, 2019).

Di dalam beberapa situs web yang membahas Indonesian Subculture, informan menyatakan bahwa Indonesian Subculture melakukan tindakan yang baik, tetap berkesenian yang aman dan sehat, dan menjadikan tato/tindik sebagai ekonomi kreatif bagus. Informan memberikan slogan "Think before you ink" yang menurutnya slogan yang patut diperhatikan sebelum orang menato tubuhnya. Menurutnya, setiap pelaku perlu memerhatikan penampilannya terlebih dahulu, disaat hidupnya belum aman karena belum dapat kerjaan, akan lebih baik untuk menato nanti. Hal ini disebabkan masih adanya stigma kriminalitas tentang tato yang membuat sebagian tempat usaha/perusahaan tidak mau menerima orang bertato.

Indonesian Subculture tidak hanya memperhatikan dari segi kesehatan saja, melainkan juga dari segi kesiapan si pelaku. Saat ini, Indonesian Subculture sudah menjadi suatu komunitas yang besar di Indonesia. Agar terus mendapatkan citra yang positif, Indonesian Subculture selalu melakukan screening terhadap orang/pemilik usaha yang ingin bergabung. Keanggotaan Indonesian Subculture terbagi menjadi dua, yaitu anggota biasa dan anggota yang diakui sebagai Indonesian Tatois.

\section{Simpulan}

Realitas tato dan piercing terkonstruksi secara negatif di masyarakat. Berdasarkan hasil wawancara yang telah dilakukan diketahui bahwa di masa lalu, tato dan piercing dipersepsikan sebagai simbol bagi seseorang atau sekelompok orang yang memiliki kekuasaan pada daerah tertentu, terutama pada kalangan mafia (proses objektivasi). Realitas mengenai tato dan piercing tersebut kemudian masuk ke Indonesia dan berkembang semakin negatif pada jaman Orde Baru akibat adanya 
"Petrus". Pada jaman Orde Baru, "petrus" menghabisi nyawa pelaku tindak kriminalitas yang mengganggu ketertiban Indonesia. Berdasarkan penelitian yang dilakukan Siegel (2000), untuk mengenali orang jahat atau berandalan, si penembak menculik orang-orang dengan gaya berandalan dan bertato (proses eksternalisasi). Dari peristiwa itulah yang membuat masyarakat mengkontruksi realitas bahwa tattoo dan piercing merupakan tanda kriminalitas (proses internalisasi).

Menurut informan penelitian ini, tato adalah sebuah seni yang tidak hidup dan hanya atribut pelengkap ditubuh. Sedangkan, di keluarga, masyarakat, serta agama yang dianut informan, tato menyalahi aturan agama dan sebagainya. Namun, narasumber tetap pada persepsinya bahwa tato adalah seni sekaligus melestarikan budaya asli Indonesia. Oleh karena itu, narasumber membentuk Indonesian Subculture untuk mengubah realitas sosial yang negatif mengenai tato di masyarakat.

Indonesian Subculture merupakan salah satu komunitas tato terbesar di Indonesia. Indonesian Subculture didirikan untuk mewadahi para pelaku tato maupun piercing, serta untuk menekan stigma negatif mengenai tattoo di masyarakat. Adanya realitas negatif tentang tato yang terkonstruk di masyarakat tentu berpengaruh pada eksistensi Indonesian Subculture beserta para pebisnis tato yang dinaunginya. Berdasarkan hasil wawancara, Indonesian Subculture memiliki perjalanan panjang hingga pada akhirnya sukses mengubah stigma negatif tattoo menjadi lebih positif di masyarakat. Kesuksesan ini tidak terlepas dari self-presentation komunitas itu sendiri.

Self-presentation yang ditunjukkan Indonesian Subculture dalam melawan stigma kriminalitas di masyarakat adalah membentuk konsep komunitas yang positif melalui slogan dan visi misi untuk selalu bertato/piercing yang aman dan sehat. Indonesian Subculture itu sendiri telah menanungi sekitar kurang lebih 700 pebisnis tato dan piercing di Indonesia yang terbagi ke dalam tiga level dan masing-masing levelnya memiliki kurikulum tersendiri. Untuk menjadi anggota Indonesian Subculture perlu melewati beberapa kualifikasi. Informan menyatakan cara untuk bergabung dengan komunitas Indonesian Subculture, antara lain mengisi formulir, lalu diserahkan sesuai dengan domisili, mendaftarkan diri sebagai anggota atau membership, memiliki coaching clinic, serta memiliki SOP yang lengkap. Setelah itu, Indonesian Subculture akan menerima pendaftar menjadi anggota.

Dengan adanya prosedur yang ditetapkan, Indonesian Subculture telah membentuk self-presentation komunitasnya sebagai komunitas yang profesional.

\section{Ucapan Terima Kasih}

Peneliti mengucapkan terima kasih dan puji syukur kepada Tuhan Yesus karena rahmat dan penyertaan-Nya peneliti diberikan kesehatan sehingga dapat menyelesaikan penelitian ini dengan tepat waktu dan tanpa hambatan. Peneliti juga mengucapkan terima kasih untuk keluarga terutama orang tua peneliti serta teman dan sahabat peneliti yang telah memberikan dukungan sehingga penelitian ini dapat selesai dengan baik.

\section{Daftar Pustaka}

Delamater, J. D., dan Myer, D. J. (2007). Social Psychology. American: Thomson Wadsworth.

Fattahurrosyid. (2016). Artikel Konstruksi Realitas Sosial Tatto: Jurnal pendidikan nonformal, Vol. 10, No. 2. Malang: Universitas Brawijaya 
Luzar. (2015). Konstruksi Realitas Sosial. Diakses dari dkv.binus.ac.id/2015/05/18/teori-konstruksi-realitas-sosial/

Myers, D. G. (1987). Social Psychology. New York: Mc Graw Hill

Meleong, L. J. (2010). Metode Penelitian Kualitatif. Bandung: Remaja Rosda Karya

Morley, M. (2002). How to manage your global reputation. New York: Palgrave

Olong, HA. K. (2006). Tatto. Yogyakarta: PT. LKiS Pelangi Aksara.

Pradhana, T. A. (2019). Self Presenting pada Media Sosial Instagram dalam Tinjauan Teori Dramaturgi Erving Goffman: Skripsi Fakultas Ilmu Sosial dan Politik, Universitas Sunan Ampel Surabaya. Surabaya.

Rahardjo, H. M. (2017). Studi kasus dalam penelitian kualitatif: konsep dan prosedurnya. Malang: Universitas Islam Negeri Maulana Malik Ibrahim

Siegel, J. T. (2000). Penjahat Gaya Orde Baru: Eksploitasi Politik dan Kriminalitas. Yogyakarta: LKiS

Sugiyono. (2020). Metode Penelitian Kualitatif. Bandung: Alfabeta

Worchel, S. E., Cooper, J., Goethals, G. R., dan Olson, J. M. (2000). Social Psychology. New Jersey: Precentice Hall.

Yoedtadi, M. G., Loisa, R., Sukendro. G., Oktavianti, R., Savitri, L. (2020). Artikel Tantangan Jurnalisme Damai Di Wilayah Pasca Konflik: Jurnal penelitian komunikasi dan opini publik, Vol. 24 No. 1, Hal. 31-44. Jakarta: Universitas Tarumanagara. 